\title{
Geochemical Processes in Peridotite Xenoliths from the Premier Diamond Mine, South Africa: Evidence for the Depletion and Refertilisation of Subcratonic Lithosphere
}

\author{
K.S. Viljoen ${ }^{1}$, I.T.M. Dobbe ${ }^{2}$, A.J. Smit ${ }^{3}$ \\ ${ }^{1}$ Mineralogy Division, Mintek, Private Bag X3015, Randburg, 2125, South Africa \\ ${ }^{2}$ FEI Electron Optics B.V., PO Box 80066, 5600 KA Eindhoven, The Netherlands \\ ${ }^{3}$ Group Exploration, De Beers Consolidated Mines, PO Box 82232, Southdale, 2135, South Africa
}

The Premier kimberlite is located in the Central Terrain of the Archaean Kaapvaal Craton (de Wit et al., 1992), with a preferred emplacement age of $1180 \mathrm{Ma}$ (Allsopp et al., 1989; Richardson et al., 1993). Underground mining operations reveal that the kimberlite, which is cut by a $1100 \mathrm{Ma}$ gabbroic sill, penetrates a norite phase of the Bushveld Complex. The Bushveld Complex is among the largest layered intrusions known, comprising a sequence of basic rocks 7-9 km thick, with an areal extent of $66000 \mathrm{~km}^{2}$ (the Rustenburg Layered Suite) and subsequent granites. The Premier diamond mine is renowned as the source of many of the world's largest gem diamonds, e.g. the Cullinan and Centenary diamonds. The locality has been the subject of xenolith studies (e.g. Danchin, 1979; Boyd and Mertzman 1987; Boyd, 1989; Boyd et al., 1993) as well as minerals occurring as inclusions in diamond (Gurney et al., 1985).

Mantle-derived xenoliths present include harzburgites and lherzolites (Danchin, 1979). Premier garnet lherzolites can be clearly subdivided into coarse and deformed varieties on the basis of differences in mineral composition and texture. Deformed lherzolites may originate from greater depths than those with coarse textures which are in turn more depleted in Fe, $\mathrm{Al}, \mathrm{Ca}$ and $\mathrm{Ti}$ relative to the deformed rocks. Constituent minerals of the deformed xenoliths are extremely titaniferous and clinopyroxenes contain significant potassium. Premier Mine garnet harzburgites are also progressively deformed and less depleted with respect to $\mathrm{Fe} / \mathrm{Mg}$ with increasing depth of origin (Danchin, 1979).

A prominent upper mantle seismic velocity anomaly within the Kaapvaal craton is associated with the Bushveld layered intrusion (Shirey et al., 2002). In this region, lower than average seismic $\mathrm{P}$-wave velocity appear to extend into the mantle beneath the layered intrusion itself, and also well to the west. Diamond populations from kimberlites located within this region of mantle lithosphere with slower P-wave velocity (including the Premier diamond mine) are characterised by a greater proportion of eclogitic versus peridotitic inclusions, a greater incidence of younger $\mathrm{Sm}-\mathrm{Nd}$ ages of silicate inclusions, a greater proportion of diamonds with lighter $\mathrm{C}$ isotopic composition, and a lower percentage of low-nitrogen diamonds (Shirey et al., 2002).

The present contribution serves to document evidence found for lithospheric depletion and enrichment in the mantle below the Premier diamond mine through the analysis of mineral and bulk rock compositional trends in garnet-bearing peridotite xenoliths. Trace element contents of garnets in the xenolith suite have been analysed, utilising laser ablation inductively coupled plasma mass spectrometry. The xenolith suite comprises of lherzolites and harzburgites (including subcalcic varieties) which have been previously studied for their major element mineral chemistry and xenolith bulk composition (Fig.1, Danchin, 1979).

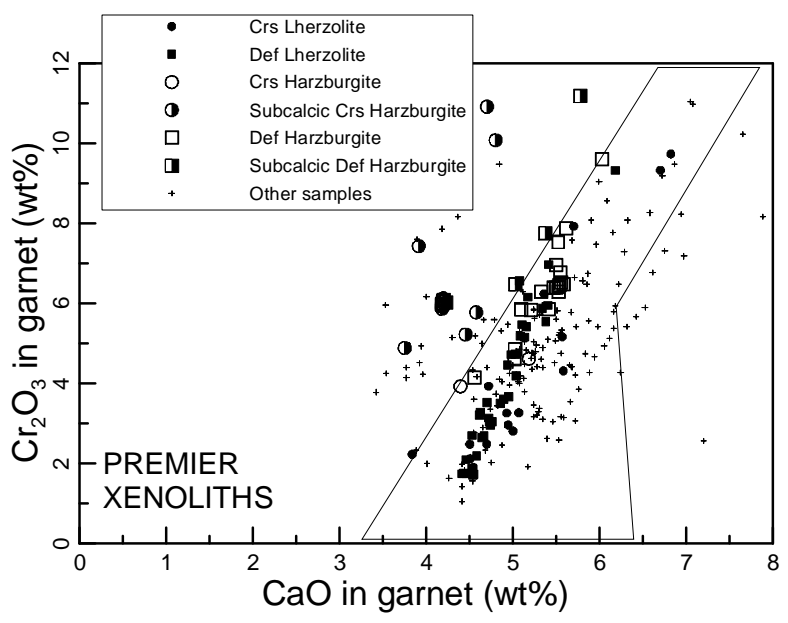

Fig. $1 \mathrm{CaO}-\mathrm{Cr}_{2} \mathrm{O}_{3}$ chemistry of garnets occurring in xenoliths from the Premier kimberlite, and which were analysed in the present study. The lherzolite region (outlined area) is after Sobolev et al (1973). Data for 'Other Samples' refer to a worldwide database.

Elevated $\mathrm{Y}$ and $\mathrm{Zr}$ contents of the garnets from coarse and deformed lherzolites, as well as deformed calcic 
harzburgites are indicative of extensive hightemperature melt-related metasomatism (Fig. 2). In contrast, coarse and deformed subcalcic harzburgites typically have lower $\mathrm{Y}$ and $\mathrm{Zr}$ in garnet, or show evidence of lower-temperature, fluid dominated metasomatism (elevated Zr only; Fig. 2). Garnet rare earth element patterns range from sinuous in e.g. the subcalcic harzburgite xenoliths to normal in e.g. the deformed lherzolites (Fig. 3). Individual garnets from some of the xenoliths show compositional heterogeneity corresponding to core-rim zonation patterns described previously for garnets in peridotite xenoliths from kimberlites (Fig. 4). The change in the shape of the rare earth element patterns from sinuous to humped to normal correlates with increasing Y content in the garnets.

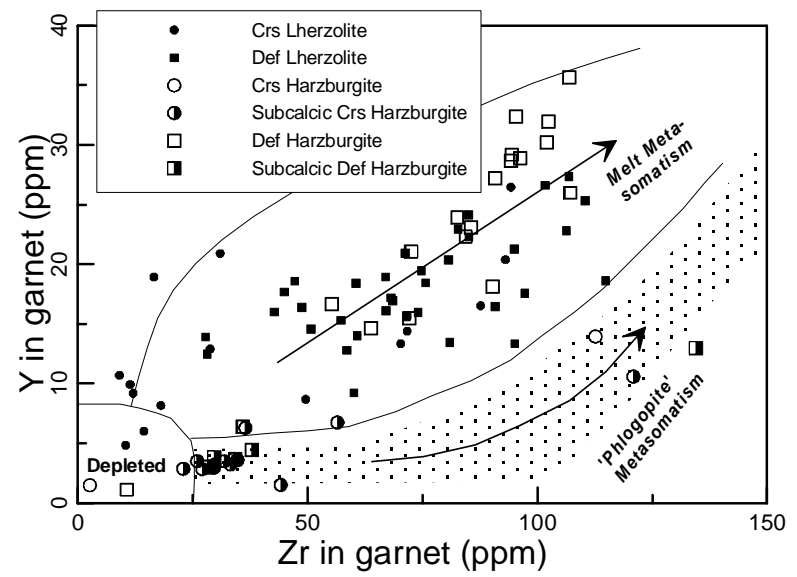

Fig. $2 \mathrm{Zr}$ and $\mathrm{Y}$ abundances of garnets occurring in xenoliths from the Premier mine. Fields and metasomatic trends after Griffin et al (1999).

Similar levels of depletion as measured by bulk xenolith $\mathrm{Al}_{2} \mathrm{O}_{3}$ content are not only evident in subcalcic and calcic harzburgite xenolith varieties, but also in a number of the lherzolites irrespective of texture (i.e. coarse vs deformed; Fig. 5) suggesting that all probably derive from the same (or similar) depleted protolith(s) but with varying levels of metasomatic overprint.

The observed trace element contents and rare earth element patterns in garnets from many of the xenoliths record evidence for substantial overprinting of the original highly depleted substrate, through melt-related metasomatism. Rare earth element patterns changed during metasomatism from sinuous to humped and finally to that typical of magmatic garnets, or garnets showing a low degree of depletion (Burgess and Hart, 2004; Stachel et al., 1997). This is consistent with the conclusion reached by Griffin et al (2003), based on compositional trends observed in peridotitic garnet xenocrysts from Premier. It is therefore considered likely that subcratonic lithosphere below Premier originally consisted solely of highly depleted harzburgite residues.

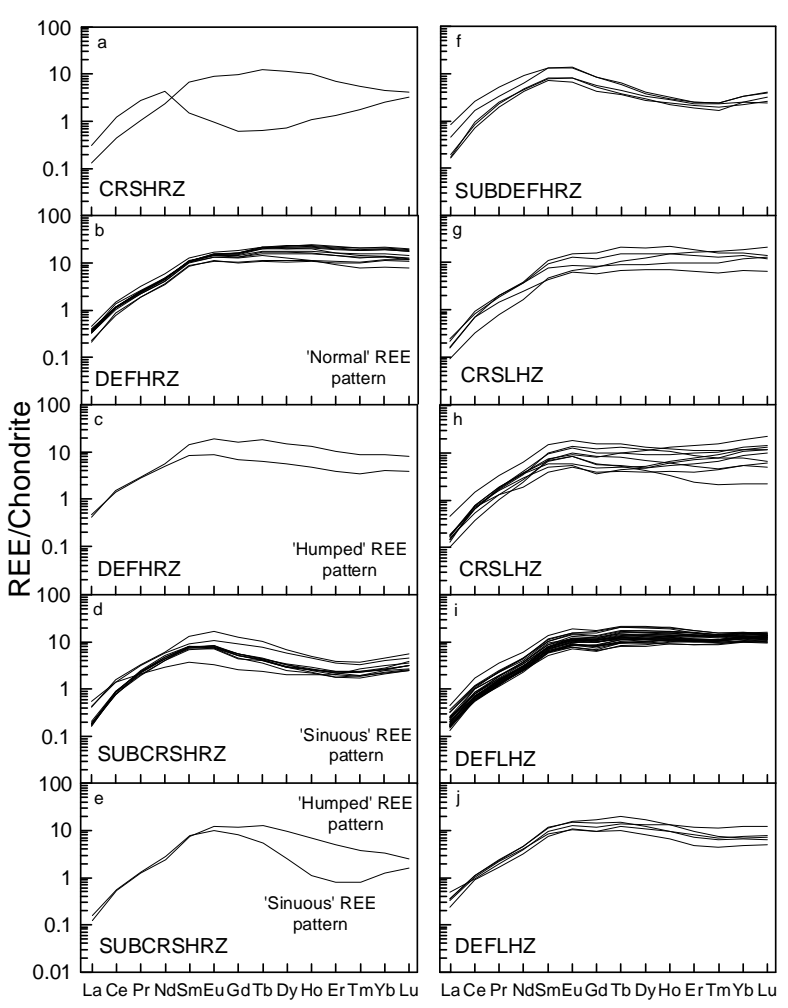

Fig. 3 Chondrite-normalised rare earth element patterns of garnets occurring in peridotite xenoliths from the Premier mine.
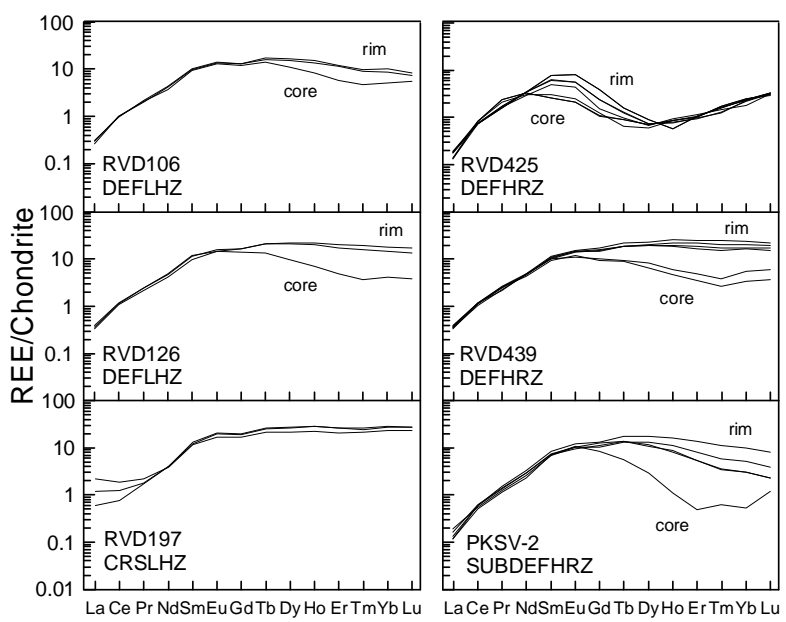

Fig. 4 Rare earth element heterogeneity in individual garnets occurring in peridotite xenoliths from the Premier mine. 


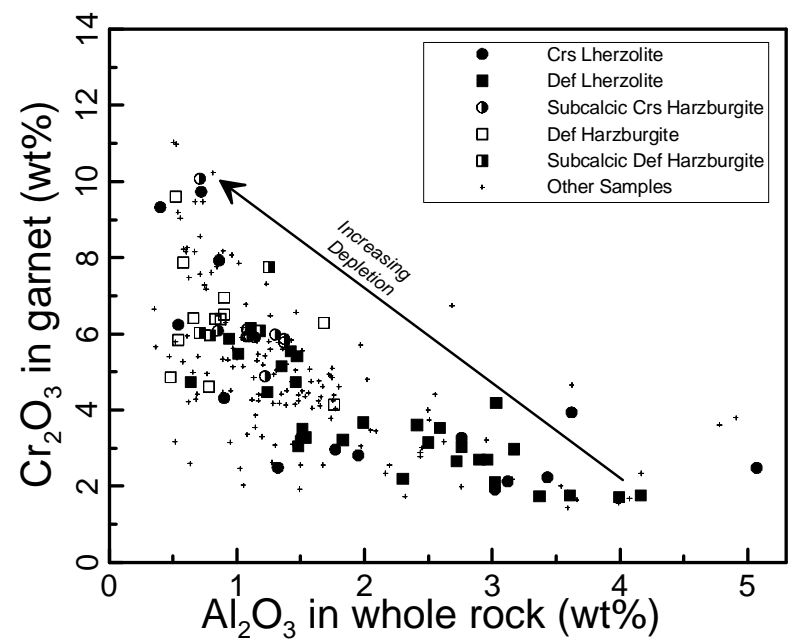

Fig. $5 \mathrm{Cr}_{2} \mathrm{O}_{3}$ content for garnets occurring in xenoliths from the Premier mine, plotted against the $\mathrm{Al}_{2} \mathrm{O}_{3}$ content of the xenolith. Data for 'Other Samples' refer to a worldwide database.

\section{References}

Allsopp, H.L., Bristow, J.W., Smith, C.B., Brown, R., Gleadow, A.J.W., Kramers, J.D., Garvie, O.G., 1989. A summary of radiometric dating methods applicable to kimberlites and related rocks. In: Kimberlites and Related Rocks, vol 1, Their composition, occurrence, origin and emplacement. Geological Society of Australia Special Publication 14, 343 - 357.

Boyd, F.R., Mertzman, S.A., 1987. Composition and structure of the Kaapvaal lithosphere, southern Africa. In: Ed B.O. Mysen. Magmatic Processes: Physicochemical Principles. Geochemical Society Special Publication 1, 13-24.

Boyd, F.R., 1989. Compositional distinction between oceanic and cratonic lithosphere. Earth and Planetary Science Letters 96, 15-26.

Boyd, F.R., Pearson, D.G., Nixon, P.H., Mertzman, S.A., 1993. Low-calcium garnet harzburgites from southern Africa: their relations to cratonic structure and diamond crystallisation. Contributions to Mineralogy and Petrology 113, 352-366.

Burgess, S.R., Harte, B., 2004. Tracing lithosphere evolution through the analysis of heterogeneous G9-G10 garnets in peridotite xenoliths, II: REE chemistry. Journal of Petrology 45, no 3, 609-634.

Danchin, R.V., 1979. Mineral and bulk chemistry of garnet lherzolite and garnet harzburgite xenoliths from the Premier mine, South Africa. In: Boyd, F.R., Meyer, H.O.A. (Eds.), The mantle sample: Inclusions in kimberlites and other volcanics. Proceedings of the $2^{\text {nd }}$ International Kimberlite
Conference, American Geophysical Union Washington, vol. 2, 104-126.

De Wit, M.J., Roering, C., Hart, R.J., Armstrong, A., de Ronde, C.E.J., Green, R.W.E., Tredoux, M., Pederby, E., Hart, R.A., 1992. Formation of an Archaean continent. Nature 357, 553 - 562.

Griffin, W.L., Shee, S.R., Ryan, C.G., Win, T.T., Wyatt, B.A., 1999. Harzburgite to lherzolite and back again: metasomatic processes in ultramafic xenoliths from the Wesselton kimberlite, South Africa. Contributions to Mineralogy and Petrology 134, 232-250.

Griffin, W.L., O'Reilly, S.Y., Natapov, L.M., Ryan, C.G., 2003. The evolution of lithospheric mantle beneath the Kalaharic craton and its margins. Lithos 71, 215-241.

Gurney, J.J., Harris, J.W., Rickard, R.S., Moore, R.O., 1985. Inclusions in Premier Mine diamonds. Transactions of the Geological Society of South Africa 88, $301-310$.

Richardson, S.H., Harris, J.W., Gurney, J.J., 1993. Three generations of diamonds from old continental mantle. Nature 366, 256 - 259.

Shirey, S.B., Harris, J.W., Richardson, S.H., Fouch, M.J., James, D.E., Cartigny, P., Deines, P., Viljoen, K.S., 2002. Science, 297, 1683-1686.

Sobolev, N.V., Lavrent'ev, Y.G., Pokhilenko, N.P., Usova, L.V., 1973. Chrome-rich garnets from the kimberlites of Yakutia and their paragenesis. Contributions to Mineralogy and Petrology 40, 39-52.

Stachel, T., Harris, J.W., 1997. Syngenetic inclusions in diamonds from the Birim field (Ghana) - a deep peridotitic profile with a history of depletion and re-enrichment. Contributions to Mineralogy and Petrology 127, 336-352. 